\title{
Re-Engineering School Libraries in Information Literacy for Sustainable Development in Nigeria
}

\author{
Dr. Adaeze, Nwona Nzewi \\ Pharmaceutical Library, Agulu Campus. NAU Awka \\ Nnamdi Azikiwe University, Awka
}

\begin{abstract}
The paper is on re-engineering school libraries information literacy for sustainable development in Nigeria. This is a theoretical paper which reviewed critically public and school library services and their role for sustainable development in Nigeria. The paper thus examined variables such as school libraries, and information literacy for sustainable development in Nigeria. The researcher therefore advocates adequate libraries funding, enforcing new library policy training and retraining of staff including availability of information and communication technology (ICT).
\end{abstract}

Keywords: RE-engineering, School Libraries, Information, Literacy and Sustainable Development

DOI: $10.7176 / \mathrm{IKM} / 10-4-06$

Publication date: June $30^{\text {th }} 2020$

\section{Introduction}

This study titled re-engineering school libraries information literacy for sustainable development cannot be overemphasis, because of deadly state of both libraries in Nigeria. Few states in this country can boast of functional school libraries services to their communities. There has been much talk about libraries, including public libraries, being uniquely positioned to act as key agents for developing the critical skill of information literacy in their communities. Yet there is a notable lack of literature addressing information literacy on school library, especially when compared to the volume of material on the topic in relation to school and other libraries, which might suggest that school libraries are not actively engaged in information literacy efforts.

Library is an indispensable center where books and non-book materials are continuously acquired and organized by trained personnel. Udoh-Ilomechine (2000) notes that school libraries help children to discover for themselves by independent study and learning how to ask questions.

Fayose (1980) asserted that for any library to run efficient services, adequate accommodation, efficient and relevant materials (books and non-books materials) and qualified personnel are required. She also added that Government needs to provide all the amenities necessary for the smooth running of libraries.

In this paper, emphasis is on re-engineering school libraries information literacy for sustainable development in Nigeria. It is over forty years since the term 'information literacy' was first coined by Paul Zurkowski (Spitzer, Eisenberg \& Lowe 1998) and nearly twenty years since the concept came to the forefront of the information profession. Libraries of all types have been charged with taking an active role in fostering an information literate society and public libraries have been presented as obvious and well equipped institutions for imparting these critical skills to the wider community.

Information literacy has been a hot issue in the library world for almost fifty decades. And it is still very pertinent today. In the age of information explosion and technological advancement, issues of information storage, organization, access, and evaluation have become important issues to be addressed by our societies. Library professionals in Nigeria, particularly in the academia, realize that information literacy plays a critical role in students' learning process. They have attempted in various ways to address issues related to information literacy and have endeavored to make information literacy an integral part of the university curriculum (Adebayo, 2012).

The goal is to help students succeed, not only during their years in college but also in their life-long career choices. "The road to information literacy is about creating relationships between ourselves and the world," and librarians are "about facilitating those connections between students and their worlds. It is thus important to make space in the traditional curriculum for the role of information literacy in the learning process so that students will be able to build a stronger foundation for their future careers.

Information literacy is a critical component of this information age. An informed citizen is the basis of an active democracy and information literacy is important for sustaining democratic institutions. The objective of the UN Literacy Decade (2003-2012) is to provide information literate environments.

\section{Concept of information Literacy}

Various concepts related to information literacy are being used in the international literature. David Bawden (2001) summarizes the terms: Computer literacy, Information Technology Literacy, E-Literacy, Library literacy, Network literacy, Internet Literacy, Hyper-Literacy, Multimedia Literacy, Media Literacy, Web literacy, Digital Literacy. One of the most frequently used definitions of Information Literacy was given by American 
Library Association (ALA) in 1989 and it states "To be information literate, a person must be able to recognize when information is needed and have the ability to locate, evaluate, and use effectively the needed information. The information literate people are those who have learned how to learn".

Horton (as cited in Lau, 2006), defines Computer Literacy as "the knowledge and skills necessary to understand information and communication technologies (ICTs), including the hardware, the software, systems, networks (both local area networks and the Internet), and all of the other components of computer and telecommunications systems". Media Literacy as "the knowledge and skills necessary to understand all of the mediums and formats in which data, information and knowledge are created, stored, communicated, and presented, i.e., print newspapers and journals, magazines, radio, television broadcasts, cable, CD-ROM, DVD, mobile telephones, PDF text formats, and JPEG format for photos and graphics". Based on UNESCO, Media and Information Literacy (MIL) (UNESCO, 2013) is made up of the following different concepts connected to each other and included in the wider concept of MIL: Computer Literacy, Digital Literacy, Freedom of Expression, Freedom of Information Literacy, Information Literacy, Internet Literacy, Library Literacy, Media Literacy, News Literacy

However in implementing information literacy programmes we need to have more specific objectives and these have been described in several ways. Campbell cited Gorman (2003) who indicated that "it is better to focus on teaching people how to utilize the information they can readily and regularly access, whether it is in a printed pamphlet from a government department, a radio programme, a newspaper - whatever is locally available." (Campbell 2008). Campbell says that the ALA definition should be applied so that the focus should "move away from teaching people what tool to use to locate information to other aspects of the information literacy definition specifically in the areas of critical thinking and awareness of information, decoding the packaging of information delivery and the appropriate use of information."

Information literacy challenges libraries, especially public and school libraries, to bring about a change in individuals' lives, to make citizens independent seekers of knowledge. Information literacy opens the avenue to promote quests for information, to develop, to expand the information base of the individual which will finally lead towards personal empowerment and lifelong learning. Democracy cannot be successful without active participation of informed citizens.

Despite all these challenges faced by public libraries in Nigeria, there is still light at the end of the tunnel. Recently, a campaign tagged "Bring Back the Book" was flagged off on the 20th of December, 2010. This campaign was aimed at resuscitating reading culture in Nigeria. This brings a ray of hope that very soon; public libraries will receive the much desired attention they deserve to serve their communities more effectively.

\section{Context of Information Literacy Services}

The end objectives of information literacy programmes can only be achieved if the public library not only makes the user aware where to get his/her relevant information but also provide it if it is not going to be easily accessible otherwise. For instance in rural areas the nearest government office may be far away and practically beyond easy reach to get a particular form. Here the public library could keep the important forms or may have the infrastructure to download the forms. Internet access is even more difficult for an individual to get. So besides making the users aware of the information available there, the public library may have to provide training on its use as well as provide some internet access within its services. Without going this extra step the IL programmes will not be implemented in spirit and its practical benefits will not reach the users.

\section{Role of Librarians in Information Literacy}

According to Joshi and Nikose (2009) Information and communication technologies have changed the complete scenario in libraries. Now a days, library has become point of resource-based learning the role of librarian is changing radically with skills of education paradigms. The impact of moving from text based learning to resource based learning will involve heavier use of library materials and a demand for more and a varied media resources, including print and non-print. The librarian is responsible for acquiring, disseminating and tracking information resources of many types. It might include database searching, interlibrary loans, monitoring internet newsgroups or maintenance of a computerized library information system. Libraries and Librarians play an important role in education of people for effective and efficient information use by teaching them information skills at all levels of education to enable to be informed citizens of the country.

\section{School libraries}

School libraries are libraries that are found in pre-tertiary institutions such as nursery, primary and secondary schools with the mission of contributing to the intellectual development of pupils and students(Agbo, 2015). It involves collection of books and other learning materials organized by trained professionals and placed in one or two big rooms in the school for the use of the pupils and teachers for learning, recreational activities, personal interest and interpersonal relationships of children in school. Further said that these enable the school 
library to fulfill functions which can be distilled as follows: i. to encourage the development of skill in reading, ii. to prompt reading habits to some literacy appreciation, iii. to sort for subject information centre and support the school curriculum and iv. to inculcate intellectual development.

School libraries are libraries in primary and secondary schools whose collections are mainly for the young. Joseph (2003) defines school library as "an organized collection of books and other learning materials placed in a school for the use of teachers and pupils who are the major patrons in the school libraries". Ogunseye (1993) sees it as "a learning resource centre of a school, responsible for making a total learning package required for students, teachers and parents". Apparently, the school library service is one of the crucial factors which facilitate the implementation of the new educational policy and objectives by promoting the efficiency and general effectiveness of learning and teaching. It provides an environment in which teachers can develop and update their knowledge and teaching skills. Learners can also find materials to supplement and enrich what has been taught in class. It also provides an independent means of education where users can work at their own pace to achieve their desired goals. Stressing its indispensability, Chima-James and Okoye (2006) purported that Secondary schools are established to prepare and train students for the challenges in the university education; therefore, a standard school library should be put in place for their effective preparation.

School libraries in the educational institutions such as pre-primary, primary and secondary schools are important to the life-wire and foundational up-bringing of children. This is because they primarily stock materials that are of interest and developmental growth for young, teenagers and youths of the era Rasaq (2000) and Edeghere (2001). However such collections of materials, to an extent make provisions for teachers, whereas the services are mainly aimed at pupils and students in the schools. School libraries are known as learning laboratory for the school. They provide the total learning package required by the students and their teachers.

Okpa-Iroha (1985), said that a school library is a collection of a wide variety of library materials and resources housed in each school, centrally organized by staff, professionally prepared to offer services to students and teachers that will enrich and support the educational enterprises.

A school library (or a school library media center) is a library within a school where students, staff, and often, parents of a public or private school have access to a variety of resources. The goal of the school libraries is to ensure that all members of the school community have equitable access to books and reading, to information, and to information technology. A school library uses all types of media is automated, and utilizes the Internet as well as books for information gathering. School libraries are distinct from public libraries because they serve as learner-oriented laboratories which support, extend, and individualize the school's curriculum. A school library serves as the center and coordinating agency for all material used in the school.

Establishment of school libraries is also meant to support school curriculum by expanding resources to enhance teaching and learning. The school library sometimes offers advice on professional development and knowledge of appropriate learning and teaching materials, including digital and non-digital media in both traditional and emerging forms. Macabre, Ugwunna, Ikechukwu and Ogu (2015) cited (Fayose, 1995) defined school libraries as that part of the school where a collection of books, periodicals, magazines and newspapers, video tapes, study kits and other information materials are kept for use by the pupils.

Furthermore, on curriculum, School library supports the school curriculum by providing up-to-date information resources and services to keep staff and students abreast of new development. The library equally involves in promoting the development of reading skills and encouraging long term reading habits through listening to and viewing a variety of learning materials. Thus, the school library system is an integral part of the school and it must be run according to agreed standards. According to National Policy on Education and School Library Standard in Nigerian, (2004) the aims and objectives of establishing school Libraries in Nigeria are:

1. Teaching students the necessary skills required in the use of the library;

2. Complementing classroom instruction by exposing the students to a wider selection of books and other resources;

3. Inculcating in students the habits of reading for pleasure, and

4. Providing users of the library with information on current issues.

Resources in school libraries are made up of print and non-print media. These are all information carriers. There cannot be a functional school library without an adequate stock of relevant and current information resources. These include textbook fictions, newspapers, films, film projector, radio, television, maps, charts, realia, tape recorders, reference items and other educational materials. Egesimba, Quadri, Dimkpa, and Ezebuike (2011) highlighted that the school library media center resources include, books, periodicals, newspapers, pamphlets, brochures, handbills, and ephemeral notices, audio materials (disc, phonographic records, audio-tapes on reels and 
cassettes), film materials (slides, film-strips, motion picture films as well as other forms of photographic film), graphics, video materials (video-tapes on reels, cassettes and cartridges as well as video disc), Realia (toys, games, model and actual specimens) and microforms (microfilm, microfiche and micro-card).

Morris (2004) also revealed that other school library resources include, Information and Communication Technology (ICT) facilities such as computers, computer diskettes, computer programmes, multi-media collection, teleconferencing, videoconferencing, audio graphic communications, Broadcast TV/Radio + audioteleconferencing and Interactive Multimedia. The author emphasized the need for annual financial provisions for the replenishment of school library. From the above analysis, it could be argued, with great emphasis that modern school library information resources should be made up of both print and non-print formats so as to enhance teaching and learning among the teachers and students. Scott (2002) related acquisition methods to the various ways by which a Library build up its collection. It is concerned with the selection and acquisition of materials for an expanding collection and the decisions on the materials to be included in that collection.

Schools used to have libraries with librarians. The general roles of the librarian were to manage a collection of print materials, promote reading and a love of good literature, and teach children how to find things in the library (James, 1998) Some librarians also kept track of filmstrips, slides, 16-mm films, audio tapes, records, and the various accompanying projectors and players (although larger schools frequently had a person called an audiovisual specialist who was responsible for maintaining, scheduling, and circulating non-print materials and equipment). Teaching children to find information was limited to the card catalog for the print collection, a guide for periodicals, and standard print reference sources such as dictionaries, atlases, almanacs, thesauri, encyclopedias, and various books of people, quotations, and places. Teaching children to find information in the library was circumscribed by the forms of information available, primarily requiring use of card catalogs, indexes, guide words, and alphabetical and numerical sequence to about the third character.

Then rapid change began. In approximately a five-year period leading out of the 1970s and into the 1990s, and now $21^{\text {st }}$, we saw video disc and half inch videocassette appear; audio cassette began to replace records; school libraries, school librarians, and audiovisual specialists were replaced by media centers and media specialists; and microcomputers showed up on desktops. The Information Age was beginning to touch schools, and as formats and sources of information proliferated, the question in media centers changed from "How do I find information in a limited number of resources?" to "How do I choose information that is most appropriate for my needs from a seemingly unlimited number of resources?" Clearly, the focus on tool skills that were specific to a particular information resource shifted to a focus on problem-solving skills generalized across many information resources. Though the researcher dwell more on school libraries, however, the situation of public libraries in Nigeria is more pathetic. more focus would be on public libraries re-engineering. There is a section of school libraries in public libraries in different states of Nigeria, but they are not doing their work to the communities.

\section{Re-engineering school Libraries for Sustainable Development through the National level}

The task of reforming and re-positioning Nigeria's libraries and information services for their anticipated role as the gateways to National and global information and knowledge in Nigeria's emerging information society is urgent, difficult and would require the commitment of library managers to a new vision of their profession, a reinventing and re-branding of library services, the implementation of new policies for library development, massive investments in technologies and information resources, increased and regular funding and, crucially, government support (Bango, 2015).

To jump-start the reform process and underline its importance, it is imperative that the Federal Government should urgently convene a high-powered national stakeholders meeting on the reform of library and information services in Nigeria. The meeting should result in affirming the important role of library and information services as gateways to information and democracy in the emerging Nigerian. Information society and approve a roadmap of vital reforms for their revitalization. It should also approve:

- $\quad$ A budget and funding plans for the reform programme

- $\quad$ Policies and guidelines on minimum standards on library funding, resources and services

- The urgent establishment of a National Commission to coordinate library services in Nigeria

- The urgent review and amendment of the National Library's statute to refocus its responsibilities in line with its new role as the hub for the national network of library and information services.

- The National Commission for Libraries and Information Services would be responsible for carrying forward the plans and policies approved at the reform meeting and for advising the appropriate governments and agencies on their implementation. Thereafter, it should, among other things:

Monitor the implementation of standards of funding and services set for various libraries 
Establish an Endowment Fund to solicit grants and donations, to be utilized for supporting the execution of strategic projects

> Plan, formulate, develop and recommend national guidelines on library services and advise governments on their implementation

$>$ Encourage private sector partnership in library development programmes

$>$ Collate, analyze and publish information relating to libraries in Nigeria.

Appraise continually the inadequacies and deficiencies of information resources and services in Nigeria.

* The National Library of Nigeria will be the hub of the national network of libraries and information services and would be responsible for developing appropriate networking tools and services. Therefore, public and school libraries connected to the network would be able to conserve their scarce resources by devoting it to satisfying the primary needs of their user community while the resources for satisfying their secondary needs are sourced from within the network. It is crucial that the importance of a viable school library system should be emphasized in the reform policies, in view of their importance in nurturing early reading and information handling skills. Appropriate recommendations should therefore be made to Federal, State and Local Government education authorities in this regard.

* Similar emphasis should be given to the urgent need for the reform of public libraries because of their unique role as the most accessible gateways to information and democracy for the vast majority of the people. Special funding should be procured to ensure that they are able to provide access to the internet and offer internet skills training to the public

* Librarians of the new information era would require skills in handling information on paper, electronic and digital formats and will be required to act as change agents. Library schools need to adjust their curricula for training new entrants to the library profession. Appropriate capacity building courses should also be arranged for the existing library manpower.

* The President, NLA and the Director/CEO of the National Library of Nigeria would have a busy time employing state-of-the-art marketing, lobbying and advocacy skills to initiate and promote this reform agenda in the months

\section{Conclusion}

Ideally, national development is dependent on the quality of information in a given contract and the role of school libraries cannot be over emphasized. This paper clearly shows the role of librarians in re-engineering school libraries for sustainable development through the national level.

\section{References}

Adebayo. O. (2012). Information as an economic resource: The role of public libraries in Nigeria. Chinese Librarianship: an International Electronic Journal retrieved from http://www.iclc.us/cliej/cl34oyeronke.pdf

Agbo A.D. (2015). School Libraries and Development of Library Skills in Nigerian Secondary Education System. Research Journal of Library Sciences. Vol. 3(2), 1-4,. Available online at: www.isca.in, www.isca.me

American Library Association (1989) Presidential Committee on Information Literacy: Final Report, http://www.ala.org/ala/acrl/acrlpubs/whitepapers/ presidential.htm

Campbell, S. (2008). Defining information literacy in the 21st century. In Information literacy: international perspectives; edited by Jesus Lau. Munchen: K.G.Saur

Bango, G (2015) Libraries as gateways to information \& democracy improving networking \& advocacy capacities in Nigeria. Keynote address workshop of Nation Library of Nigeria

Jackson, S (1995). Information literacy and public libraries: a community-based approach in Information for a new age: redefining the librarian, Libraries Unlimited, Inc. Englewood, Colorado.

Jehlik, T (2004). Information literacy in the public library', electronic version, Nebraska Library Association Quarterly, vol. 35, no. 4, pp. 7-13, http://www.nebraskalibraries.org/nlaquarterly/2004-4Jehlik.htm

Jane Harding (2013). Information literacy and the public library: we've talked the talk, but are we walking the walk? http://www.tandfonline.com/loi/ualj20

James O. Carey (1998) Library Skills, Information Skills, and Information Literacy: Implications for Teaching and Learning Research Journal of America association school librarians Volume 1, www.ala.org/aasl/slr

Joseph, K. (2003). What to know about library. Ibadan: Kay Jay Publishers 
Joshi, P and Nikose (2009) How to achieve best services to students through information literacy for an academic library. http//www.ala.org

Chima-James, N \& Okoye, I. B. (2006). Materials of the secondary school libraries, vis-à-vis standards. Nigerian Library and Information Science Trend. 4 (1\&2) : 63 Framework: Country Readiness and Competencies (p. 150). Paris: Un.

Ogunseye, F. A. (1993). The library media factor in the implementation of the new secondary school syllabus. Nigerian School Library Journal. $3(1 \& 2): 1-5$

Spitzer, K, Eisenberg, MB, \& Lowe, CA (1998) Information literacy: Essential skills for the information age, ERIC Clearinghouse on Information and Technology, Syracuse, New York. 